\title{
The Legacies of Tennis Champions Althea Gibson, Arthur Ashe, and the Williams Sisters Show the Persistence of America's Race Obstacles
}

\author{
Yven Destin ${ }^{2} \cdot$ Ervin Dyer $^{1}$ \\ Accepted: 14 May 2021 / Published online: 26 May 2021 \\ (c) The Author(s) 2021
}

\begin{abstract}
Black athletes have had to express a double consciousness of being American and being Black. By exploring the biographies of pioneering tennis figures-Althea Gibson, Arthur Ashe, and the Williams sisters-Venus and Serena-one can look at their encounters with racism and their quests for self-respect and explore the social implications of race in the USA. To understand race and its complications on the world in which black tennis players navigate, we broadly look at racial discrimination in their lives using the lens of sociological concepts such as "the color line" hypersegregation and "American Apartheid;" the controlling image thesis and respectability politics, and class mobility in and outside the black community. The concepts connect to illuminate the racial constructs and structures the players operated in and which shaped in the process of becoming a sports champion. Through their biographies, we argue that it is possible to interrogate the ways in which America's longstanding racial policies, prejudices, and perspectives have had a persistent impact on not only the lives of black tennis players, but the lives of black Americans.
\end{abstract}

\section{Introduction}

In the American experience, black athletes have raised both the flag and their fists. They have suffered defeat and indignities. They have earned championships and criticism. It is because of race they have had to express this double consciousness of being American and being Black. It was no different for black athletes in professional tennis. By exploring the biographies of pioneering tennis figures-Althea Gibson, Arthur Ashe, and the Williams sisters-Venus and Serena-one can look at their encounters with racism and their quests for self-respect and explore the social implications of race in the United States. Biographies, or stories of individuals, are always intertwined with broader social and cultural networks, so information gained through

Ervin Dyer

ervindyer@gmail.com

Yven Destin

Yven.destin@gmail.com

518 E. North Ave, Pittsburgh, PA 15212, USA

25715 Oakcrest Green Drive, Apt. 201, Charlotte, NC 28217, USA biographical research can help one to understand the wider society (Erben, ).

To understand race and its complications on the world in which black tennis players navigate, we broadly look at racial discrimination in their lives using the lens of sociological concepts such as "the color line," hypersegregation or "American Apartheid," the controlling image thesis and respectability politics, and class mobility in and outside the Black community. The concepts connect to illuminate the racial constructs and structures the players operated in and were shaped by in the process of becoming a sports champion.

One can argue that the social implications of race took a pointed turn with The US Supreme Court's ruling in favor of "separate but equal" accommodations in the 1896 Plessy v. Ferguson case that gave federal sanction to Jim Crow ordinances and laws throughout the American South (Sellers, 2020). Coming before the dawn of the century in which the four trailblazing tennis athletes were born, the sanctioning of a Jim Crow law passed in Louisiana in 1890 not only instituted "separate railway carriages" but also created the first African American Interstate Tournament (Walker, 2017a). For the next 100 years, and beyond, laws deliberately created by whites in a series of private decisions and institutional 
practices (Massey \& Denton, 1993) created a racialized world that Black tennis players would have to negotiate.

\section{Althea Gibson}

Althea Gibson's rise to the international tennis circuit was not easy. Born in Silver, South Carolina in August 1927, she was the daughter of a cotton sharecropper. In a time of Great Depression and a declining cotton market hit by drought and boll weevil plague, her father realized that this work would never yield enough to provide for his family (Gray \& Lamb, 2004). As recounted in her biography, "The big man, he buy the cotton. He gave you the lowest he could give you for it" (Gray \& Lamb, 2004). Sharecropping in the South exploited Black labor and locked Blacks into a caste system of limited opportunities for advancement until the Great Migration (Massey \& Denton, 1993). By 1870, eighty percent of Blacks lived in the rural South, oppressed by the sharecropping system of whites renting land to Blacks for crops. A century later, eighty percent of them would live in urbans areas, and nearly half were located outside the South (Massey \& Denton, 1993).

When Gibson was about 2, her father joined the nearly 34,000 others migrating to New York (Gray \& Lamb, 2004), seeking a better life in the diverse and stratified Harlem. But by the time the family arrived, the thriving Black Renaissance of arts and culture that shaped Harlem was over and they settled in an economically depressed community on 143rd Street. Nonetheless, very quickly Gibson became a standout for her skills with paddle tennis, a game played on the streets of Harlem. At the age of 12, she became the New York City women's paddle tennis champion in 1939, a year before Black tennis phenom Jimmie McDaniel played white tennis world champion Don Budge in the first ever interracial match in tennis history at Harlem's Cosmopolitan Tennis Club (Shmerler, 2021). Gibson's skills brought her to the attention of the famed Tennis Club, a space reserved for the community's Black elite (Miller, 2015). The club's middle-class members enjoyed lawn tennis but because of their race were not allowed into the country clubs of their white counterparts. So, the color line forced them to form their own.

Blacks have had an interest in the sport of tennis since black colleges and universities first began offering the British version of the French sport in the 1880s. But in the wave of racial segregation, the game, too, came under the sway of Jim Crow, formally barring black tennis players from white tournament competitions. The black tennis clubs of Washington, D.C., and Baltimore Maryland, conceived of the American Tennis Association (ATA), the oldest Black sports organization in American history (ATA, 2020). As tennis had been a sport introduced to college students, it naturally became a marker of social status, a sport of the "Black bourgeoisie," (Teele, 2002) who mirrored their white counterparts, who were prim, educated and exhibited social graces. Gibson was an odd fit with the Cosmopolitan. She lacked the proper education and class background, but her athletic ability was impressive and club leaders and coaches began to teach her the social graces of the tennis game and offer her what Afro-American studies professor Evelyn Brooks Higginbotham (1993) later described as the politics of respectability in the African American community by which they knew she would be judged (Harris, 2003).

There were perhaps other reasons the Black elite was interested in Gibson. Amid the sensation of Jackie Robinson, who had re-integrated Major League Baseball, ${ }^{1}$ the Black tennis elite was interested in developing an African American to break the US color line in tennis. Gibson was the best prospect. By this time, in 1946, Gibson was 18 and a champion with the ATA. She fell under the mentorship of the Godfathers of Black tennis: Robert Walker Johnson, a physician in Lynchburg, Virginia, who learned tennis at Lincoln University, a historically black university; and Hubert Eaton, a dentist in North Carolina who was a men's doubles champion in the ATA (CSPAN, 2018; Walker, 2017b). They believed Gibson could be groomed to be the first Black to play in the US Lawn Tennis Association, the mecca of US tennis.

To prepare her, Gibson went South, training with Eaton in North Carolina and with Johnson in Virginia, where she played with the best Black players in America. In these segregated communities, an aspect of Black life sometimes looked back on with some fondness of a more supportive time (Bates, 2014), Gibson found people who cared for her and built up her confidence and foundation. She benefited from "the closeness that came from a group forced to live together because of their race" (Bates, 2014). But going South was to travel deeper into the system of American apartheid. Gibson had to adhere to the Southern mores of a racially divided world. She sat on the back of buses in Wilmington, N.C. As Black players traveled to tournaments, they were threatened, called "nigger," and had hate notes left on their sleeping quarters, often in local YMCAs, telling them to go home (Miller, 2015). As was customary, to not antagonize and solicit violence from white spectators and whites at rest stops, the players were taught to be tough and not to fight back in the face of such racism as their behavior could make it worse for the people who came behind themwhich was a prominent response, a racial uplift ideology that talented Black people had a responsibility to uplift the Black race (Du Bois, 1903; Gaines, 1996). In preparing to enter

\footnotetext{
${ }^{1}$ Moses Walker Fleetwood of the Toledo team was the first Black player to integrate major league baseball in 1884 .
} 
the white tennis establishment, Eaton and Johnson knew it was important to teach Gibson not only tennis skills, but also etiquette that aligned with the polite behaviors of white society and worked to disassociate the negative stereotypes of Black people. She would need to be gentle on the court, not to question or argue calls about the lines. She would have to be on her best behavior, as she would be representing not only herself, but also her race (Miller, 2015).

For decades, the United States Tennis Association (USTA) had no written rule barring Blacks; players qualified for the Nationals by accumulating points at sanctioned tournaments, most of which were held at white-only clubs. By the time she broke through the Jim Crow regulations, Gibson had amassed a record of wins that included the ATA New York State Championship (1941) ATA national championship in the girls' division (1944 and 1945) and ten straight national ATA women's titles (1947 to 1956) —all in a world that was of, by, and for Black people. Her counterpart, Rob Ryland, won back-to-back men's ATA singles titles in' 55 and'56. However, 10 years earlier, in 1946, he broke the color line and became the first Black to play in the all-white NCAA. Four years later, Gibson would follow Ryland into the all-white tennis world, one where the clothes, socks, the balls, and the players, everything was visually and institutionally entrenched in white (ness) (Miller, 2015). Not surprisingly, despite the lobbying from Johnson and Eaton, and Gibson's record of achievement, it took protestations from a white former champion to secure the invitation. Retired athlete Alice Marble, who had played exhibition doubles with Ryland, openly challenged the segregation and bigotry and wrote it was ridiculous to reject Gibson because of the color of her skin. "We can accept the evasions," she wrote, "or we can face the issue squarely and honestly" (Marble, 1950).

So, on a sunny August day in 1950, Gibson, her hair relaxed in curls, became the first Black American to play in a major all-white tennis event. Some 2000 people jammed the Forest Hills Stadium. Outside the gates, some shouted "beat the 'nigger!'" Gibson narrowly lost after a rainstorm pushed the second-round match into the next day, but her imposing, graceful style of play left an impression.

Shortly after the tournament, Gibson enrolled at historically Black Florida A\&M University, finishing at age 27 with a bachelor's degree in 1955. The next year, 1956, she obtained a milestone when she crossed the color line in international tennis, becoming the first African American to win a Grand Slam title, the French Championships. The following year she topped the tennis world when she won both Wimbledon and the US Nationals (precursor of the US open). She won both again in 1958. In all, she won 11 Grand Slam titles: five in singles, five in doubles, and one mixed doubles title.
Her Wimbledon win came when she was 29 years old. She met Queen Elizabeth and earned a tickertape parade in New York, greeted by thousands as "a champion in a world of champions" 2 as she rode down Broadway's Canyon of Heroes. In 1957, after her US championship, she earned a standing ovation and Vice President Richard Nixon presented her the trophy. She was hailed as the queen of Harlem. Yet, there were still places in America where she couldn't eat, rest, or vote because of the color of her skin. Despite her wins, America still did not see Blacks as equals.

Gibson's win at Wimbledon in 1957 came on the heels of the school desegregation movement after the Brown v. Board of Education ruling in 1954, Emmett Till's lynching in 1955 and the Montgomery Bus Boycott that ended victoriously in 1956. Jackie Robinson retired from baseball in 1957 and began a life of quiet civil rights activism, which seemed to define the role of the Black athlete until Muhammed Ali took center stage a decade later embodying the tradition that: "given a voice, given the platform provided by their feats on the field or the court" the Black athlete must "take on the responsibility of speaking for those who don't have that platform" (Vognar, 2018). In the climate of the civil rights movement, as the 'female Jackie Robinson,' (O'Reilly, 2012) there was certainly public pressure to comment on the racial significance of her accomplishments and to speak on the changing racial landscape. Gibson's path-breaking achievements gave her a platform, but it was not a role she seemed to welcome.

First, she had to deal with the narrative of discrimination that faced other Black athletes: that they were graced with athletic ability but lacked sports intelligence and acumena persistent racial stereotype that suggests Black people's natural athletic ability requires no discipline or work ethic (Stone et al. 1997). Second, mainstream America wanted to relegate her to being a sports entertainer, while she was a serious competitor with an assertive style of play that was said to intimidate opponents. Third, because she was often derided on and off the court as being too masculine for the sport of tennis (Nauright et al. 2014), a closeted lesbian (Miller, 2015), she had every reason to be reticent of being on a platform. In the 1950s, women were seen as being second class, especially Black women, says Leslie Allen (WNET, 2015), a professional tennis player who was once coached by Gibson. "They had to be demur. Althea was proud. But that's not who Buffy and Muffy want at the tennis club. She was very strong, but she was seen as being out of place."

All these factors were what Black feminist scholar Patricia Hill Collins (1991) coined as controlling images,

\footnotetext{
2 Part of the post-ticker tape parade speech by Borough of Manhattan
} President, Hulan E. Jack. 
imbued with ideas that attempted to justify her role in the minds of white and Black Americans; it was something she would be acutely aware of throughout her career and posttennis life. Such was the case when, early in her career, the US State Department perhaps relying on her as the "female Jackie Robinson" sent her to Southeast Asia on a goodwill tennis tour. She was keenly aware of the use of her image when in a news report, she was quoted:

I've never been exactly sure why I was selected to make the tour. It happened soon after the murder of Emmett Till in Mississippi, and world opinion of the racial situation in the United States was at a low ebb. So, I suppose that was the main reason why I, a colored girl, was invited to help represent our country in Southeast Asia. I certainly wasn't picked because I was a champion; at the time, I was champion of nothing and unlikely ever to be (Lansbury, 2001).

After her tournament successes, Gibson won no favors with advocates of the Civil Rights movement when, at a press conference, after being asked whether she faced any great hurdles because of her race in getting to the top of the tennis world, she answered, "No, I don't think that there are any obstacles as far as race is concerned" (Miller, 2015). Indeed, as she would admit in her autobiography (Sundiata, 2006): "I don't consciously beat the drum for any special cause, not even the cause of the Negro in the United States, because I feel that our best chance to advance is to prove ourselves as individuals." So, against the public pressure to fulfill her role as a "race hero," Gibson seldom went out of her way to warm up to people, particularly the bourgeois of the tennis world (Miller, 2015).

Despite not being more vocal about race prejudice, Gibson's success did not buffer her from it. She couldn't go to the locker rooms, she had to change in kitchens, she was not allowed in the tennis clubhouse. Despite winning 11 major titles and partly because she played during an era before tennis was unionized, she was not afforded the same privileges and support as the white female players. Gibson, arguably the best female player in America, had to quit the tour to make a living. She tried other ways to support herself, before she suffered health problems and became reclusive by the 1990s, and tennis, in effect, had turned its back on her (Miller, 2015).

Gibson's legacy was briefly revived in 2001 after she was featured on the cover of the iconic Wheaties cereal box and again when tennis champion Serena William, who later graced the cover of the box, gave tribute to the pioneering Gibson in an Instagram post (Williams, 2019). In 2019, Gibson was memorialized with a statue at the US Open (Branigan, 2019).
Gibson represented her nation, her sport, and her race with great dignity and pride. When she died in 2003, she was accomplished but underappreciated. About her career, in which she faced racism, she wrote: "it has been a bewildering, challenging, exhausting experience. Often more painful than pleasurable, more sad than happy" (Gibson, 1958).

\section{Arthur Ashe}

Arthur Ashe was born in 1943 and raised in Richmond, Virginia, the former Capital of the Confederacy, a city that enforced racial segregation in housing, medical care, education, employment, and transportation. In the South, Blacks had to be conscious of the street that racially divided their communities; they entered downtowns where most daily business occurred surrounded by symbols of racial segregation, including "Whites Only" and "Coloreds Only" signs. Public parks were also segregated. It was this environment that Ashe would later recount that as a skinny 12-year-old, he and his coach were turned away from a tennis tournament held at one of Richmond's "Whites Only" parks. Ashe, recalling his disappointment yet newfound determination to break the color line, said he went away "knowing that the only reason I could not play was because I was Black" (Livingstone, 2015). He faced other incidents of legalized racism. When he rode public transportation, the white driver asked him to move behind the white line on the bus. No matter his tennis achievement or grades, he could not enroll at the University of Virginia, the state school founded by Thomas Jefferson, because of the color of his skin.

For Ashe, being Black in the segregated South left him "a marked man," a feeling he described as being, "forever aware of a shadow of contempt that lays across my identity and my sense of self-esteem... the shadow is always there; only death will free me, and Blacks like me, from its pall" (Ashe and Rampersad 1994). He also lived in an era when Blacks suffered beatings, lynchings, and killings, which produced an oppositional culture as tensions between Blacks and the white system would flare up from time to time (Massey \& Denton, 1993).

However, much like with Gibson, it was the segregated Black community - parts of it elite and professional-that nurtured Ashe and prepared him for the larger world he would eventually have to navigate. "One of the major tasks of my teachers as I grew up," Ashe once recounted, "was to make sure that no Black kid gave up the struggle to do better because of despair in the face of segregation. We were taught that segregation counted for nothing against our duty to ourselves to work hard and do well" (Ashe and Rampersad, 1994).

As a young player, Ashe took lessons from the pioneering Ryland, who won ATA championships alongside Gibson 
(Walker, 2017b) and who was granted a chance to play at Forest Hills (Bembry, 2020), six years after Gibson's trailblazing match there. But at age 35, Ryland had passed his prime, winning only a few tournaments, and wondering "if I could have made it big, with the right backing" (Friedman, 1964). However, in 1959, Ryland made history when he turned professional, the first Black player to do so, earning the nickname the "Jackie Robinson of Tennis." His decision came a full decade before Ashe, who once dreamed of being "good enough to beat Bob Ryland" (Bembry, 2020), turned professional.

As Ashe developed, he also found community with the same tennis coaches who had taken Gibson under their wings. Ashe spent multiple summers with Johnson's Junior Development program in Lynchburg, getting trained in the temperament of Jackie Robinson to prove to the world in the 1960s that Blacks could compete in the face of racial hate. Ashe aspired to become the Jackie Robinson of tennis (ESPN, 2013). And, he did. He won the US Open in 1968 and Wimbledon in 1975, becoming the first Black man and the second Black player in American history to win formerly all-white national championships. Gibson was the first. As of today, no other Black American man or African-descended man has won the US Open or Wimbledon. Yannick Noah, a player of Cameroonian and French descent, won the French Open in 1983.

Outside of tennis, Ashe was a disciplined and erudite man-a patriot, really. After he graduated from the University of California Los Angeles with a business degree, he served in the US Army, at West Point as a data processor. He didn't go to the theater of war in Vietnam, but later went there in a different capacity as a member of the US Davis Cup, an international team competition. There he represented America in exhibitions and gave tennis clinics on a goodwill tour. Regardless of his participation in these established social institutions, he could not escape what he called the "burden of race," forever aware of the shadow of contempt—Du Bois' double consciousness. He remained a Black man, in a very white world. Even on the tennis court.

He forever struggled with reconciling the two dimensions of his life, the distorted ways a white and Black world viewed him, trying to thrive on both sides on what Du Bois (1903) described as the "veil". He wrote in his 1993 memoir "Days of Grace" "I see nothing inconsistent about being proud of oneself and one's ancestors and, at the same time, seeing oneself as first and foremost a member of the commonwealth of humanity." Yet, sadly, he admitted that a "pall of sadness hangs over my life and the lives of almost all African Americans because of what we as a people have experienced historically in America" (Ashe \& Rampersad, 1993). The twoness was exhausting. It left him worrying about how others would react to seeing his daughter playing with a white doll given to her by a friend. He found himself always counting the dark faces in the room, trying to determine their reason for being there and always, sadly, finding too many Blacks in service positions. And, even though both his parents suffered heart illness, the stress of the twoness most likely contributed to his having a heart attack at age 36 , despite the physical fitness required with being a professional athlete. The trauma African Americans endure reflects a sort of racialized stress that gnaws away at family life, interpersonal relationships, self-esteem, and eventually, the physical health of Black people (Billingsley, 1992; Jackson \& Sears, 1992; Krieger \& Sidney, 1996; Landrine \& Klonoff, 1996; McMurray et al., 1999). Ashe said that battling race was a more difficult battle than fighting HIV, which can be a fatal disease. "Being Black is the greatest burden I've had to bear. Race has always been my biggest burden. Having to live as a minority in America ... It feels like an extra weight tied around me" (Ashe \& Rampersad, 1993).

Ashe particularly felt the racial burden when historical events pushed race front and center. His career intersected with the assassination of the Reverend Dr. Martin Luther King, Jr. and Robert F. Kennedy, and the aftermath of riots and social unrest raging across the nation in 1968. Tennis was not an official sport at the 1968 Mexico Olympics, so Ashe did not attend. However, protests of the games and in Mexico deeply challenged the tennis champion to speak out on America's racial issues. With the death of King and presumably the end of the Civil Rights movement, Black empowerment began to sweep the nation. Propelled by the Student Non-violent Coordinating Committee (SNCC), which fused education with activism, emerging voices such as Harry Edwards, Bill Russell and Muhammad Ali represented a new, more militant kind of Black athlete activism (CSPAN, 2019). Among them, Edwards, then a young sociology professor, created the Olympic Project for Human Rights in association with SNCC. The project called for a boycott of the Mexico Olympics to protest racism in sports. At the Olympics, track champions John Carlos and Tommie Smith raised their hands in Black Power salute on the awards podium. However, the moderate Ashe-mindful of being connected to the militant image of the Black man-declined Edward's call to boycott (Livingstone, 2015). Critics cast Ashe as an "Uncle Tom," someone obsessively loyal, obedient and "slavish to white authority" (Livingstone, 2015).

Ashe's decline of Edward's boycott request in 1968 was a second instance of when his racial integrity had been questioned. A week prior, at the request of a mentor, Ashe spoke to a church audience about the proper role and responsibilities of Black athletes in the era of civil rights. He discussed what he called the "negative effects of Black laziness and complacency" (Arsenault, 2018). He was quoted: "There is a lot we can do and we don't do because we're lazy... This may be brutal, but poverty is half laziness" (Arsenault, 2018). His comments won him praise in the mainstream 
media, which described his philosophy as "Me Power," a 'Black people, Do-It-Yourself" attitude (Livingstone, 2015) and his approach to addressing social issues as a person "possessing an intriguing level headedness and states his case without the polemics that sometimes seems to have become associated with the civil rights movement, pro and con" (Arsenault, 2018). For Edwards and advocates of Black militancy, however, Ashe's decline to boycott and his controversial speech were proof of his subservient nature to white people.

Ashe's slow march to activism set him apart from the constraining controlling images of the emergent "angry Black athlete," and one who is known just for his natural athletic ability. His form of activism-marked by "an attachment to careful deliberation and rhetorical understatement" (Arsenault, 2018)-helped to unionize male players under the Association of Tennis Professionals, which he co-founded and once presided over. In the 1980s, he would extend his activism against the spread of HIV/AIDS after he contracted the disease.

Whatever the case, Ashe preferred a different kind of change-making. He fought with his racquet, working mostly behind the scenes pushing for "tennis-for-all" initiatives that targeted urban and minority youth. One legacy of this kind of activism was the Williams sisters-Venus and Serenawho participated in these leagues as young players.

A testament to his activism on a global scale occurs in early 1970s, when Ashe went to South Africa, which at the time operated under a brutal apartheid system and many Black people had called for a boycott of the nation to protest its policies. It was a controversial visit and Ashe, though he would lose the tournament match, visited the townships, believing it was important for the marginalized Black South Africans to see a Black professional tennis player. He found other ways to use tennis to contribute to the world and he found causes off the court, too. He captained the US Davis Cup team; he wrote a memoir and the encyclopedic a hard road to glory: a history of the African American athlete (Ashe et al., 1988), he became an anti-apartheid advocate.

Ashe died from AIDS-related pneumonia on February 6,1993 . After he passed, he was memorialized in ways he probably could have never imagined. In 1997, the USTA named its US Open stadium for the pioneering player. Arthur Ashe Stadium is in Queens, N.Y., part of the Billie Jean King National Tennis Center. Most impressively, a monument to Ashe stands in his hometown, Richmond, Virginia, on Monument Boulevard, a few blocks from the park where Ashe was not allowed to play as a boy because he was Black. The other irony: the Ashe monument, where the tennis player holds a book higher than he holds a racquet, sits on a grand boulevard of statues dedicated to Confederate heroes, the very architects of White supremacy who fought for the South to remain segregated and for Blacks to remain enslaved. When the Richmond City Council granted permission to place Ashe's memorial there, and as an example of America's enduring racist legacy, several protestors in Confederate uniforms showed up at the city council meeting. Now, in recent weeks, after the summer 2020 police murder of George Floyd and the uprising that followed, many of the Confederate statues have come down either by decree from Richmond's African American mayor or from citizen protesters detowering them. The Ashe statue, though vandalized by Confederate supporters, remains standing. As the legacy of white supremacy appears to face a reckoning, a Black tennis player who tried his best to overcome it all, remains at the center of attention in the former Confederate capital. How's that for fighting back and rising above it all.

\section{Williams Sisters}

The Williams sisters, Venus and Serena, were not born in Compton, California. But they grew up there, learning tennis on the community's tattered public courts. In their father's 2014 memoir, black and white: The way i see it, Richard Williams writes about the tension with gang members and fighting for the opportunity to have safe access to the unkempt courts near his home. "It had taken two years and almost destroyed my body and my spirit," but it did become a safe space, he writes. And, in that moment, "What mattered was the courts were ours."

In the 1990s, the Williams family lived in Compton in a time of crack cocaine and of extraordinarily violent street gangs as Hip Hop was making Compton an international symbol of urban chaos (Sides, 2011). The Compton the sisters grew up in was an under-resourced, socially isolated urban space that made it hard for the Williams family to establish beneficial networks. It was an impoverished community that could destabilize social and economic wellbeing and negatively control an individual, a family, and a generation's life chances because of the connection to joblessness, poverty, welfare reliance, failing schools (Anderson, 1999; Massey \& Denton, 1993; Rainwater, 1970). These conditions could have been a real threat to the sisters' professional tennis development. As inequalities are often parallel to race and class divisions, the distinctions become a "color line" that push groups into a lower social order, effectively limiting their mainstream assimilation (Bonilla-Silva, 2003; Du Bois, 1903).

Despite it all, Richard Williams had a vision for his daughters. He often talked about how he watched a tennis match on television and awed by the prize money; he determined he would turn his daughters into champions. If he had to start on an unkempt court, so be it (Price, 1999).

Unlike Gibson and Ashe who were catapulted into fame by a Black elite in the sports era of Jackie Robinson, Venus 
and Serena Williams benefitted from the sports era of Michael Jordan, the NBA superstar who became a popular cultural icon. Whereas the Black elite saw Gibson and Ashe as having the potential to be the next Jackie Robinson, white recruiters like Rick Macci, saw Venus Williams as having the potential of becoming the next Jordan-to which Richard Williams replied, "No, Mr. Macci, we've got the next two Michael Jordans" (Pina \& Uschan, 2016). Since the 1970s, "the black athlete was finally being recognized and rewarded" thanks in part by black athlete activism amid the Civil Rights and Black Power movements (Chin \& Christian, 1996). The convergence of televised sports and the explosion of Black athletes, who gradually became the new face of sports, created a highly visible, highly marketable Black superstar (Chin \& Christian, 1996). With the added financial support of corporate America, brand-name products featuring popular athletes like O.J. Simpson created a sports culture heavy in endorsements, which by the 1990s catapulted basketball's Jordan beyond super stardom (Chin \& Christian, 1996).

The Williams sisters, straight out of the storied streets of Compton, Black Cinderellas of sort, along with their remarkable tennis skills seem to captivate spectators and affirm their Jordanesque rise in the tennis world. The appeal of an impressive Black player amid talk of integrating sports triggered white tennis player Alice Marble to lobby for Gibson's entry in the white world of tennis. This could easily be compared to a similar appeal of the Williams sisters as being the next Black phenoms who triggered Macci to coach them and secure their entry into a still predominantly white tennis sport.

Nevertheless, when Venus was about 10 or 11, their father, conscious of the exploitive nature of athletics, and wanting to protect his children's future careers, stopped sending his daughters to national junior tennis tournaments (Baird \& Major, 2012). At that time, Venus Williams held a remarkable 63-0 record on the USTA junior tour and was ranked No. 1 among the under-12 players in Southern California (Edmondson, 2005). Experiences of racism on the tour further fueled their father's decision as he said he heard white parents talk about his daughters in a derogatory manner during tournaments (Peyser \& Samuels, 1998).

When they left the Florida academy, for much of their early professional tennis career, the sisters took the unconventional step of being coached by their parents, Richard and Oracene Williams who had never played professional tennis. True to the ingenuity of Black people who faced impossible odds, the Williams parents laid the foundations for Venus and Serena's highly successful tennis achievements. Venus Williams became a seven-time Grand Slam title winner in singles, and Serena Williams amassed 23 Grand Slam titles and is in pursuit or record-tying 24th. Each sister has been ranked No. 1 in the world, a feat matched by no other siblings in tennis history.

When Venus Williams won Wimbledon in 2000, she became the first African American woman since Althea Gibson in 1958 to win the English championship. She had this to say in reflecting on the milestone by Gibson and herself: "It had to be hard because people were unable to see past color. Still, these days, it's hardly any different because you realize it's been only 40 years. How can you change ... centuries of being biased in 40 years?" (Navratil \& West, 2000).

Yet 50 years after Gibson faced racial taunts for playing in an American tournament, the Williams sisters would face comparable insults. In 2001, at a tournament in Indian Wells, California, a year after Venus won Wimbledon, both sisters would encounter racism. In the semifinal, when the sisters were scheduled to compete against each other, Venus Williams pulled out four minutes before the start of the match with an injury, citing tendinitis. There were rumors that their father had fixed the match by asking his daughter to step aside. The next day, Serena Williams played the final-and won-against Kim Clijsters; but during the match her father claimed he heard racist epithets hurled at his daughter. $\mathrm{He}$ said he heard one man utter: "I wish it was' 75 , we'd skin you alive." The sports announcer during the televised broadcast commented that it was an "American crowd booing an American family; and you have to say that it does smack of a little bit of racism" (Baird \& Major, 2012). The incident occurred a year after the sisters won Gold for the US at the 2000 Sydney Olympics and sadly in their home state of California, two hours south of Compton.

Thus, the Williams sisters, despite their accolades and success, and the so-called racial progress since the Civil Rights movement, were reminded of the shadow of racial contempt that continued to exist in sports and the wider nation. In speaking on the incident, Serena Williams responded: "I don't know if race has anything to do with this particular situation. But in general, I think, yeah, there's still a little problem with racism in America" (Drucker, 2009).

The Williams sisters always seem to not be able to escape being racialized, sexualized, or dehumanized. In the fall of 2014, Russian Tennis Federation president Shamil Tarpischev was fined $\$ 25,000$ by the Women's Tennis Association and suspended from tour involvement for a year for questioning Serena and Venus Williams' gender on Russian television. He had described Venus and Serena as the "Williams brothers," a disgusting statement that is maddeningly familiar to derisions of Gibson. A writer for Ms. Magazine slammed Tarpishchev's comment as body shaming, wrapped in a "triad from hell: misogyny, racism and transphobia" (Gaston, 2014).

Serena Williams, who has a particularly stellar tennis career, seems especially targeted for racialized bigotry aimed at her body size and shape and dimensions of her 
power game. Far too often, Black athletes are represented as an "unthinking black body" — athletes who are invariably strong, powerful and quick but who supposedly lack cognitive capabilities at critical moments (Carrington, 2001). It's a controlling image that distinguishes them from their white peers, who are often described as having composure and genius at critical moments. One sportswriter said this is why Serena Williams is criticized as having a 'natural advantage,' "as if her incredible ability is getting in the way of the Eastern European porcelain blondes just behind her in the ranking” (Whelan, 2015). After her win against Lucie Šafářová at the French Open in 2015, a social media commentator wrote that Williams "looks like a gorilla and sounds like a gorilla when she grunts while hitting the ball. In conclusion, she is a gorilla" (Desmond-Harris, 2017).

In 2008, scholars James McKay and Helen Johnson wrote in the journal Social Identities, about what they called the "pornographic eroticism and sexual grotesqueries in representations of African American sportswomen." Their argument is that sports is used as a lens through which white people are encouraged to analyze how they construct and view Black people. This lens often uses commentary on Serena Williams that is grounded in stereotypes about Black people being animalistic and aggressive and Black women, in particular, as being masculine, unattractive, and overly sexual at the same time.

Anita Little, writing in Ms. Magazine, in 2012, emphasized the historical racialization and sexualization of Black women. She linked the racialized sexualization of Serena Williams's physique to the legacy of the "Hottentot Venus," an African woman whose real name was Saartjie Baartman, who was displayed before European audiences as a freak show attraction in the 1800 s. "No matter how insanely successful black women like Serena become, the legacy of the Hottentot Venus will always be ready to rear its ugly head at an opportune moment," Little wrote (2012).

It's very possible the stereotypes play into the economics of tennis, too. In 2015, Serena Williams had \$13 million in endorsements and Maria Sharapova, who's lost to Serena Williams all but two times they've played each other, had $\$ 23$ million in endorsements (Chase, 2015).

There are many explanations to consider, but a central rationale points to long-held prejudices regarding femalessports stars included-and symbols of beauty and what's bankable (Meier \& Konjer, 2015). What's at play is a bigoted mix of prejudice, sexism, and racism. Maria Sharapova is thin, blonde, and white. Serena Williams is muscular, curvier, and Black.

In 2015, in an article in the New York Times Magazine, Serena Williams took the high road in addressing the issue.

If they want to market someone who is white and blond, that's their choice. I have a lot of partners who are very happy to work with me. I can't sit here and say I should be higher on the list because I have won more. I'm happy for her, because she worked hard, too. There is enough at the table for everyone. We have to be thankful, and we also have to be positive about it so the next black person can be No. 1 on that list.

\section{Conclusion}

Althea Gibson, Arthur Ashe, and the Williams sisters were pioneering professional Black tennis players. Their achievements made history. But being Black in America also meant they could not escape history. When it was illegal for Blacks to sit at the front of the bus, it was illegal for Gibson and Ashe to do so, too. When Black women are subjugated to racialized images of being hypersexualized and animalistic, Venus and Serena Williams, being in the white-hot spotlight of world champions, cannot escape the racist glares and commentary. Just like with any Black athlete, these tennis pioneers cannot escape the unfolding of historical events that swirls around them.

The social forces that link the lives of these professional tennis players to America's racial legacy unfortunately have their impact on the next generations of aspiring Black athletes, too. It is important to note that the challenges Gibson, Ashe, and the Williams sisters have endured reflect systemic racial barriers that continue to shape Black adolescents' participation in the sport of tennis. In 2013, USTA conducted its first nationwide study of the educational, behavioral, and health benefits of adolescent tennis participants. The study revealed minorities (one of several categories used to measure tennis participation) appeared to be underrepresented among tennis participants. Compared to the racial composition of contact sports (e.g., football) and other non-contact sports (e.g., swimming) to that of tennis participants, the racial composition within the sport of tennis comprised of 77\% White, 9\% Black, and 14\% Hispanic. When measured at the time against the demographic of the US population of $72.4 \%$ White, $12.6 \%$ Black, and $16.3 \%$, Black adolescents showed to be underrepresented among tennis participants. The study also showed that odds of a Black male adolescents playing tennis were $46 \%$ lower compared with their White counterparts. The odds of Black female adolescents playing tennis were " $24 \%$ less likely than White females to participate in tennis" (USTA, 2013).

The study suggested policy implications for USTA, among them targeted recruitment and retention programs. While USTA's study did not measure the impact of racism on adolescent tennis participants, in fact the word "racism" does not even appear anywhere in the report, it's hard to see how the tennis association will mitigate the racial disparity of their youth participants who are likely to face some of the 
systemic racism faced by Gibson, Ashe, and the Williams sisters without a thorough study of the impact of racism on their players.

Through the biographies of Gibson, Ashe, and the Williams sisters, it is possible to interrogate the ways in which America's longstanding racial policies, prejudices, and perspectives have had a persistent impact on not only the lives of Black tennis players but the lives of Black Americans. Because their lives and sports achievements are intertwined with society as a whole, they offer a glimpse of the social impact of racialization not only in tennis but also the wider American community. Embedded in their stories is the struggle with segregation, personal indignities, and overcoming.

Open Access This article is licensed under a Creative Commons Attribution 4.0 International License, which permits use, sharing, adaptation, distribution and reproduction in any medium or format, as long as you give appropriate credit to the original author(s) and the source, provide a link to the Creative Commons licence, and indicate if changes were made. The images or other third party material in this article are included in the article's Creative Commons licence, unless indicated otherwise in a credit line to the material. If material is not included in the article's Creative Commons licence and your intended use is not permitted by statutory regulation or exceeds the permitted use, you will need to obtain permission directly from the copyright holder. To view a copy of this licence, visit http://creativecommons.org/licenses/by/4.0/.

\section{References}

American Tennis Association. (2020). History. YourATA.org. Retrieved July 24, 2020, from https://www.yourata.org/history

Anderson, E. (1999). The cultural territories of race: Black and white boundaries. University of Chicago Press.

Arsenault, R. (2018). Arthur Ashe: A life. Simon \& Schuster.

Ashe, A., Branch, K., Chalk, O., \& Harris, F. (1988). A hard road to glory: A history of the African-American athlete. (Vol. 3). Warner Books.

Ashe, A., \& Rampersad, A. (1994). Days of grace: A memoir. Ballantine Books.

Baird, M., \& Major, M. (2012). Venus and Serena. Magnolia Pictures. Retrieved August 6, 2020, from https://www.youtube.com/ watch?v=8c_w_q60NcM\&t $=3261 \mathrm{~s}$

Bates, K.G. (2014). Nostalgia for what's been lost since 'brown v. board.' Code switch, from NPR, May 17. Retrieved August 6, 2020, from https://www.npr.org/sections/codeswitch/2014/05/14/ 312555307/nostalgia-for-whats-been-lost-since-brown-v-board

Bembry, J. (2020). Bob Ryland loved tennis until he very end. The Undefeated, August 4. Retrieved August 6, 2020, from https://theundefeated.com/features/ bob-ryland-loved-tennis-until-the-very-end/

Billingsley, A. (1992). Climbing Jacob's Ladder: The enduring legacies of African-American families. Simon and Schuster.

Bonilla-Silva, E. (2003). Racial attitudes or racial ideology? An alternative paradigm for examining actors' racial views. Journal of Political Ideologies, 8(1), 63-82.

Branigin, A. (2019). Althea Gibson, the first black athlete to integrate tennis, finally gets her flowers with new statue. TheRoots.com.
Retrieved July 24, 2020, from https://theglowup.theroot.com/ althea-gibson-the-first-Black-athlete-to-integrate-ten-1837591629

Carrington, B. (2001). Fear of a black athlete: Masculinity, politics and the body. New formations. 45 (winter). Retrieved August 6 , 2020, from https://www.lwbooks.co.uk/new-formations/45/fearof-black-athlete-masculinity-politics-and-the-body

Chase, C. (2015). Why does Maria Sharapova earn $\$ 10$ million more in endorsements than Serena Williams? For The Win, September 1. Retrieved August 6, 2020, from https://ftw.usatoday.com/2015/09/ serena-williams-addresses-why-maria-sharapova-earns-10-milli on-more-in-endorsements

Chin, M., \& Christian, J. (1996). Journey of the African American athlete. $H B O$. HBO Studio Productions. Retrieved August 6, 2020, from https://www.youtube.com/watch?v=DJETqeSY17 $0 \& \mathrm{t}=5606 \mathrm{~s}$

Collins, P. H. (1991). Controlling images and Black women's oppression. In J. J. Macionis \& N. Vaicaitis (Eds.), Seeing ourselves: Classic, contemporary, and cross-cultural readings in sociology 4.Prentice Hall.

C-SPAN. (2018). Dr. Robert Johnson and tennis desegregation. C-SPAN.org. Retrieved July 10, 2020, from https://www.c-span. org/video/?440464-1/dr-robert-johnson-tennis-desegregation

C-SPAN. (2019). Black athletes' activism. C-SPAN.org. Retrieved August 6, 2020, from https://www.c-span.org/video/?457943-2/ Black-athletes-activism

Desmond-Harris, J. (2017). Despite decades of racist and sexist attacks, Serena Williams keeps winning. Vox.com. January 28. Retrieved August 6, 2020, from https://www.vox.com/2017/1/28/14424624/ serena-williams-wins-australian-open-venus-record-racist-sexistattacks

Drucker, J. (2009). What happened at Indian Wells? ESPN.com. March 11. Retrieved August 6, 2020, from https://www.espn.com/sports/ tennis/columns/story?columnist=drucker_joel\&id=3952939

Du Bois, W. E. B. (1903). The souls of black folks. A. C. McClurg \& Co.

Edmondson, J. (2005). Venus and Serena Williams: A biography. Greenwood Publishing.

Erben, M. (1998a). Biography and research method. Social Research and Educational Studies Series, 19, 4-17.

Erben, M. (Ed.). (1998b). Biography and education: A reader. (Vol. 19). Falmer Press.

ESPN. (2013). Arthur and Johnnie. Season 1, Episode 13, 30 for 30 shorts, from ESPN.org. Retrieved August 6, 2020, from https:// www.amazon.com/gp/video/detail/B00TZOBLXM/ref=atv_dp_ season_select_s1

Freidman, C. (1964). Bob Ryland traveled the back roads of tennis. The New York Times, June 21. Retrieved August 6, 2020, from https://www.nytimes.com/1964/06/21/archives/bob-ryland-trave led-the-back-roads-of-tennis-negro-stars.html

Gaines, K. K. (1996). Uplifting the race. University of North Carolina Press.

Gaston, C. (2014). Serena and Venus Williams battle more bodyshaming. Ms. October 23. Retrieved August 6, 2020, from https:// msmagazine.com/2014/10/23/serena-and-venus-williams-battlemore-body-shaming/

Gibson, A. (1958). I always wanted to be somebody. HarperCollins.

Gray, F. C., \& Lamb, Y. R. (2004). Born to win. Wiley.

Harris, P. J. (2003). Gatekeeping and remaking: The politics of respectability in African American women's history and black feminism. Journal of Women's History, 15(1), 212-220.

Higginbotham, E. B. (1993). Righteous discontent: The Women's movement in the Black Baptist Church, 1880-1920. Harvard University Press.

Jackson, A. P., \& Sears, S. J. (1992). Implications of an Africentric worldview in reducing stress for African American women. Journal of Counseling \& Development, 71(2), 184-190. 
Krieger, N., \& Sidney, S. (1996). Racial discrimination and blood pressure: The cardia study of young black and white adults. American Journal of Public Health, 86(10), 1370-1378.

Landrine, H., \& Klonoff, E. A. (1996). African American acculturation: Deconstructing race and reviving culture. SAGE Publishing.

Lansbury, J. H. (2001). "The Tuskegee flash" and "the slender Harlem stroker": Black women athletes on the margin. Journal of Sport History, 28(2), 233-252.

Little, A. (2012). Serena Williams, the Hottentot Venus and accidental racism. Ms. magazine, December 15. Retrieved August 6, 2020, from https://msmagazine.com/2012/12/15/serena-williams-thehottentot-venus-and-accidental-racism/

Livingstone, S. (2015). Arthur Ashe: More than a champion. $B B C$. Retrieved August 6, 2020, from https://www.youtube.com/ watch? $\mathrm{v}=\mathrm{FX} 09 \mathrm{hjb} 4 \mathrm{XYA \&} \mathrm{t}=661 \mathrm{~s}$

Marble, A. (1950). A vital issue. American Lawn Tennis Magazine, July 1. Retrieved August 6, 2020, from http://res.cloudinary.com/ ithf/image/upload/v1521727703/The_Alice_Marble_and_Althea_ Gibson_Letters.pdf

Massey, D., \& Denton, N. (1993). American Apartheid: Segregation and the making of the underclass. Harvard University Press.

McMurray, R. G., Harrell, J. S., Bangdiwala, S., \& Deng, S. (1999). Cardiovascular disease risk factors and obesity of rural and urban elementary school children. The Journal of Rural Health, 15(4), 365-374.

Meier, H. E., \& Konjer, M. (2015). Is there a premium for beauty in sport consumption? Evidence from German TV ratings for tennis matches. European Journal for Sport and Society, 12(3), 309-340.

Miller, R. (Director). (2015). American masters: Althea. Season 29, Episode 6. B.J. King (Executive Producer) New York, NY: PBS. org

Nauright, J., Gobley, A. G., \& Wiggins, D. K. (2014). Beyond CLR James: Shifting boundaries of race and ethnicity in sports. University of Arkansas Press.

Navratil, W., \& West, C. (2000). "It's like a menu. They can look,..." Chicago Tribune. July 19. Retrieved August 6, 2020, from https:// www.chicagotribune.com/news/ct-xpm-2000-07-19-0007190124story.html

O'Reilly, J. (Ed.). (2012). Women and sports in the United States: A documentary reader. University Press of New England.

Peyser, M., \& Samuels, A. (1998). Tennis: The brash Williams sisters. Newsweek International Edition., 132, 44-49.

Pina, A., \& Uschan, M. V. (2016). Serena Williams: Tennis Ace. Greenhaven Press.

Price, S.L. (1999). Who's your daddy? Vault. May 31. Retrieved August 6, 2020, from https://vault.si.com/vault/1999/05/31/ whos-your-daddy-call-richard-williams-what-you-wantbizarredeceitful-or-perhaps-madbut-be-sure-of-one-thing-he-has-brill iantly-guided-the-careers-and-lives-of-his-daughters-venus-andserena-the-hottest-players-in-tennis

Rainwater, L. (1970). Behind ghetto walls. Transaction Publishers.

Sellers, Jr., C.L. (2020). The legalized segregation of the races in South Carolina arose as a part of white Carolinians' long reaction to emancipation and reconstruction. South Carolina encyclopedia, s.v. segregation. Retrieved July 24, 2020, from http://www.scenc yclopedia.org/sce/entries/segregation/
Sides, J. (2011). Josh Sides — the rise of hip hop and the black fightpop culture and Compton's image. In Z. Behrens (Ed.), Social focus, from KCET. January 20. Retrieved August 6, 2020, from https://www.kcet.org/socal-focus/is-nwas-straight-outta-comptonan-accurate-historical-social-commentary-of-that-city

Shmerler, C. (2021). Overlooked no more: Jimmie McDaniel, tennis player who broke barriers. The New York Times, February 11. Retrieved May 1, 2021, from https://www.nytimes.com/2021/02/ 11/obituaries/jimmie-mcdaniel-overlooked.html

Stone, J., Perry, W., \& Darley, J. M. (1997). "White men can't jump": Evidence for the perceptual confirmation of racial stereotypes following a basketball game. Basic and Applied Social Psychology, 19(3), 291-306.

Sundiata, D. (2006). Blacks at the net: Black achievement in the history of tennis. (Vol. 1). Syracuse University Press.

Teele, J. E. (Ed.). (2002). E. Franklin Frazier and black bourgeoisie. University of Missouri Press.

USTA. (2013). USTA serves special report, more than a sport: Tennis, education and health. Retrieved August 6, 2020, from http://www. asandaces.org/uploads/4/3/2/4/43244011/tennis_-more_than_a_ sport_full_report_2.27.13_1_1.pdf

Vognar, C. (2018). When star Black athletes consider it their duty to speak up for social justice. The Dallas Morning News. Retrieved June 1, 2018, from https://www.dallasnews.com/opinion/comme ntary/2018/06/01/when-star-Black-athletes-consider-it-their-dutyto-speak-up-for-social-justice/

Walker, R. (2017). The rich and nuanced history of black people in tennis. The Undefeated. Retrieved July 30, 2020, from https://theundefeated.com/features/the-rich-and-nuanced-histo ry-of-black-people-in-tennis/

Walker, R. (2017). Althea Gibson, Arthur Ashe highlight a century of ATA champions. The Undefeated, August 4. Retrieved August 6, 2020, from https://theundefeated.com/features/althea-gibsonarthur-ashe-highlight-a-century-of-ata-champions/

Whelan, D. (2015). Does tennis have a race problem? Vice.com. June 18. Retrieved from https://www.vice.com/en_us/article/pg5njm/ does-tennis-have-a-race-problem

Williams, S. (2019, June 25). In 2001, Wheaties paid homage to a true champion and an icon by putting her on the cover of a Wheaties Box. Althea Gibson was the first Black Woman tennis player to be on the box. Today, I am honored to be the second [photograph]. Retrieved July 24, 2020, from https://www.instagram.com/p/BzIjZ h0HoVc/?utm_source=ig_embed

WNET. (2015). Panel discussion: American Masters: Althea. WNET and the Schomburg Center for Research in Black Culture. Retrieved August 6, 2020, from https://www.youtube.com/ watch? $\mathrm{v}=$ ynEXEO3oeRY\&list=PLAITttqas35b6F64hL9q9dLq iFmqv--Hz\&index $=9$

Publisher's Note Springer Nature remains neutral with regard to jurisdictional claims in published maps and institutional affiliations. 